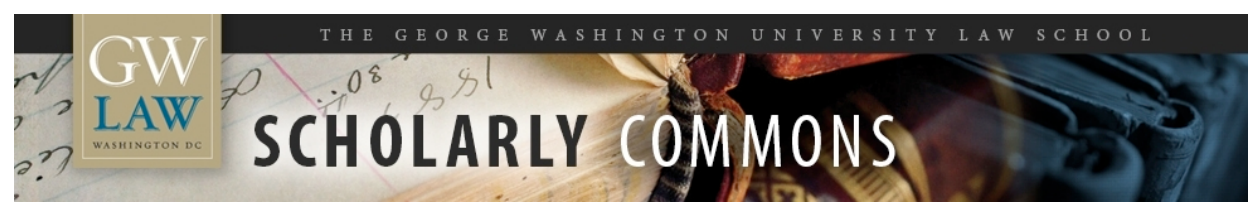

\title{
The Labor Dimension of the Emerging Free Trade Area of the Americas
}

Steve Charnovitz

George Washington University Law School, scharnovitz@law.gwu.edu

Follow this and additional works at: https://scholarship.law.gwu.edu/faculty_publications

Part of the Law Commons

\section{Recommended Citation}

Steve Charnovitz, The Labor Dimension of the Emerging Free Trade Area of the Americas in LABOUR RIGHTS AS HUMAN RIGHTS (Philip Alston, ed., Oxford, 2005)

This Book Part is brought to you for free and open access by the Faculty Scholarship at Scholarly Commons. It has been accepted for inclusion in GW Law Faculty Publications \& Other Works by an authorized administrator of Scholarly Commons. For more information, please contact spagel@law.gwu.edu. 


\title{
The Labor Dimension of the Emerging Free Trade Area of the Americas
}

\author{
Steve Charnovitz*
}

\section{Introduction}

Negotiations for a Free Trade Area of the Americas (FTAA) began over six years ago and are slated to be finished by 2005. ${ }^{1}$ The nations of the Americas could certainly benefit from freer trade, as Latin America is afflicted with widespread poverty, high unemployment, and the most unequal income distribution in the world. ${ }^{2}$ So far, no formal talks on labor have been held. That could change as the FTAA nears completion in 2004 or thereafter.

The purpose of these lectures is to explore a labor dimension for the FTAA. This study is divided into four parts: Part 1 provides context by reviewing the history of Inter-American economic cooperation, especially on labor and trade. Part 2 examines how labor has been addressed in the major free trade agreements of the Americas. Part 3 looks at the normative basis for international labor cooperation. Part 4 makes specific recommendations for addressing labor issues in the FTAA.

\section{Historical Context}

The significance of labor as an FTAA issue cannot be understood by looking only at the FTAA negotiations that commenced in April 1998. Although the official FTAA website traces the FTAA's 'antecedents' as far back as the 1st Summit of the Americas held in December $1994^{3}$, the story actually begins 170 years earlier — when Simon Bolívar inspired the first assembly of the

\footnotetext{
*George Washington University Law School, June 2004. This is the draft version of the paper that will appear in Philip Alston, ed., Labour Rights as Human Rights (Oxford, 2005).

${ }^{1}$ See generally José M. Salazar-Xirinaches and Maryse Robert (eds), Toward Free Trade in the Americas (Brookings, 2001). The negotiations include all countries in the Americas except Cuba.

${ }^{2}$ Report of the ILO Director-General, Globalization and Decent Work in the Americas, $15^{\text {th }}$ American Regional Meeting, December 2002, at 10-13.

${ }^{3} \mathrm{Http} / / /$ www.ftaa-alca.org/View_e.asp.
} 
American Republics. This 1824 Congress of Panama, as it became known, was convened to consider an agenda of political, collective security, and commercial issues. The Congress produced a Treaty of Perpetual Union, League, and Confederation which, although postponing the topic of commercial relations until the next assembly, dealt with a number of controversial issues, such as the abolition of the African slave trade. ${ }^{4}$ This Treaty did not go into force, however, and no follow-up assembly was held. Hemispheric cooperation puttered along over the next several decades in seeming perpetual discord.

The Western Hemisphere resurged in 1889 when the United States took the lead in convening and hosting the International American Conference. ${ }^{5}$ The promotion of regional trade and dispute settlement were among the top goals for that endeavor. The Conference concluded that while free trade among the nations of the hemisphere was a premature idea, interested governments might seek partial reciprocity treaties with one or more countries as it may be in their interest to do. ${ }^{6}$

This First ${ }^{7}$ Pan American Conference sparked new treaties and institutions that, in fits and starts, propelled continental economic and social cooperation over several decades. The International Bureau of American Republics was established in 1890 and became the Pan American Union in 1910. In 1948, the Pan American Union was transformed into the Organization of American States

\footnotetext{
${ }^{4}$ Peter Blanchard, 'Pan Americanism and Slavery in the Era of Latin American Independence,' in David Sheinin (ed), Beyond the Ideal. Pan Americanism in Inter-American Affairs, (Praeger, 2000), 9, at 9-18; Josef F. Kunz, 'The Idea of “Collective Security” in Pan-American Developments,' 6 Western Political Quarterly 658 (1953); Joseph Byrne Lockey, Pan-Americanism. Its Beginnings (MacMillan, 1920), at 312-345. The proposals to liberalize trade were blocked by Mexico. Samuel Guy Inman, Inter-American Conference 1826-1954: History and Problems (University Press and Community College Press, 1965), at 9.

${ }^{5}$ Javier Corrales and Richard E. Feinberg, 'Regimes of Cooperation in the Western Hemisphere: Power, Interests, and Intellectual Traditions,' 43 International Studies Quarterly 1, at 5 (1999).

${ }^{6}$ The International Conferences of American States 1889-1928 (Carnegie Endowment, 1931), at 3334.

${ }^{7}$ In deference to tradition, I spell out the ordinal numbers denominating the early Pan American conferences. This will also distinguish them from the nomenclature of the recent conferences.
} 
(OAS), which, together with the Rio Treaty for collective security, solidified the foundation for the Inter-American human rights system and many other fields of regional cooperation.

The Summit of the Americas of 1994 was not the first hemispheric summit, but it almost seems that way because it revitalized regional cooperation to promote democratic values and economic prosperity. ${ }^{8}$ Today, the Inter-American system operates through a vibrant triad of: (1) formal institutions (the main ones being the OAS and the Inter-American Development Bank), (2) periodic transgovernmental Summits and conferences, and (3) partnerships with business and civil society organizations.

State participation in the system has been nearly universal with a few notable exceptions: Canada did not join the OAS until 1990. Cuba was made unwelcome at the OAS after 1962, a fate that did not befall other countries that suffered periods of dictatorship. The English-speaking Caribbean countries began entering the OAS in the 1960s.

The remainder of Part 1 will discuss the course of labor cooperation in the Americas during the past century. No comprehensive study of this topic has come to my attention, and my goal here is merely to highlight some of the key milestones. Some commentators may dismiss this history as being inconsequential because of the seeming lack of governmental follow-up. A sound judgment needs to await new scholarship using both institutionalist and constructivist lenses.

Labor and social issues surfaced only occasionally in the early conferences. At the Second Pan American (Mexico City) Conference of 1901-1902, the governments formulated a Convention on the Practice of Learned Professions designed to make it easier for professionals in one country to practice in another. ${ }^{9}$ The Fifth Pan American (Santiago) Conference of 1923 called on governments to promote vocational training through the exchange of teachers and workmen. The Conference

\footnotetext{
${ }^{8}$ See Robin L. Rosenberg, 'The OAS and the Summit of the Americas: Coexistence, or Integration of Forces for Multilateralism?,' 43 Latin American Politics and Society 79 (2001).

${ }^{9}$ Convention on the Practice of Learned Professions, 27 January 1902, 6 Martens (3d) 191.
} 
further agreed that international questions relating to social problems should be included on the program of all future conferences. ${ }^{10}$

Alongside the hemispheric cooperation, there were also other efforts. For example, in 1923, a Conference of Central American Affairs approved a General Treaty of Peace and Amity, as well as some specialized treaties, including a Convention for the Establishment of Free Trade and a Convention on the Unification of Protective Laws for Workmen and Labourers. ${ }^{11}$ The Unification Convention of 1923 was notably progressive - particularly with regard to prohibiting involuntary labor and providing for compulsory insurance - because similar norms were not achieved in the International Labour Organization (ILO) until years later.

The Pan American system was also remarkable for devoting attention to discrete social matters. The First American Child-Welfare Congress convened in 1916 with organizational assistance from the League of Women's and Child's Right. ${ }^{12}$ Earlier child welfare and nutrition congresses had been held in Europe, and, as with much of the functional international networking of that era, the initiative and energy came from nongovernmental organizations (NGOs) working closely with technical experts and government officials. In 1927, the Fifth Pan American Child Congress established an International American Institute for the Protection of Childhood, which continues to operate today as the Inter-American Children's Institute, a specialized organ of the OAS.

Although there is some overlap between children's rights and labor rights, the two fields are distinguishable. The Pan American cooperation on children is noted here because it has been more active than the labor cooperation. One reason might be is that although the multilateral ILO existed for labor issues, children's issues lacked global institutions and therefore bloomed better at the

\footnotetext{
${ }^{10}$ The International Conferences of American States, supra note 6, at 260-266.

${ }^{11}$ Manley O. Hudson (ed), International Legislation, Vol. II, at 901 et seq.

${ }^{12}$ Seventh International Conference of American States, 'Fifth, Sixth and Seventh Committees' (1933), at 59-60.
} 
regional level. The same point can be made about the Inter-American Commission on Women, founded in 1928, which preceded and inspired later developments at the global level. ${ }^{13}$

The Sixth Pan American (Havana) Conference of 1928 approved a resolution on Emigration and Immigration which called for the principle of equality of civil rights as between nationals and foreigners. ${ }^{14}$ The entire immigration issue proved controversial, however, as states jealously guarded their autonomy. For example, the United States insisted that 'the control of immigration is a matter of purely domestic concern.... ${ }^{15}$ Yet some states saw a common interest in more open borders. For instance, El Salvador proposed no state not place obstacles to emigration and immigration among American states.

In 1933, the Seventh Pan American (Montevideo) Conference approved several labor-related resolutions. For example, the Conference called on governments to facilitate freedom of association, to adopt the principle of 'family income' in order to increase 'human capital,' and to establish a register of immigration possibilities in each country. ${ }^{16}$ Another resolution called for a 'Campaign Against Unemployment,' including measures to facilitate local, national, and international commerce. The Conference also sought the establishment of an Inter-American Labor Institute with a mandate to develop recommendations and principles for the solution of American social problems which were thought to have features 'distinctive from, if not in conflict with European problems' being dealt with by the ILO. ${ }^{17}$ Among the valuable principles slated for discussion was 'that the machine must be

\footnotetext{
${ }^{13}$ Myres S. McDougal, Harold D. Lasswell, and Lung-chu Chen, Human Rights and World Public Order (Yale 1980), at 644-645.

${ }^{14}$ The International Conferences of American States, supra note 6, at 378-381.

${ }^{15}$ Id. at 380.

${ }^{16}$ The International Conferences of American States. First Supplement 1933-1940 (Carnegie Endowment, 1940), at 92-93, 238-240, 270.

${ }^{17}$ The International Conferences, First Supplement, supra note 16, at 39-41.
} 
considered as a helper of man and not as his substitute.' For various reasons, the hopes to establish the Institute proved unsuccessful.

Attention to labor issues continued during World War II. In 1942, a Meeting of Ministers of Foreign Affairs of the American Republics made a series of recommendations, one of which was that international agreements or long term contracts should provide 'a fair standard of wages for the workers of the Americas, in which producers are protected against competition from products originating in areas wherein real wages are unduly low.... ${ }^{18}$ The Ministers also asked for input regarding postwar problems from the Inter-American Juridical Committee. In response, the Juridical Committee put forward several recommendations, including the need to 'guarantee to each individual a degree of economic security ... necessary to enable him to develop his personality.... ${ }^{19}$ With regard to its social recommendations, the Committee observed that the 'realization of these objectives is primarily the task of each separate State, but only by parallel international action can they be adequately secured. ${ }^{20}$

In early 1945, the Inter-American Conference on Problems of War and Peace (known as the Mexico City or Chapultepec Conference) approved an 'Economic Charter of the Americas' containing 10 guiding principles. The first principle was for governments to direct economic policies toward the creation of conditions which will encourage, through expanding domestic and foreign trade and investment, the attainment everywhere of high levels of real income, employment and consumption, free from excessive fluctuations, in order that their peoples may be adequately fed, housed, and

\footnotetext{
${ }^{18}$ Final Act of the Third Meeting of Ministers of Foreign Affairs of the American Republics, January 1942, 36 AJIL Supp. 61, at 64 (1942).

${ }^{19}$ 'Preliminary Recommendations on Postwar Problems,' International Conciliation, No. 387, February 1943, 101, at 125.

${ }^{20} \mathrm{Id}$.
} 
clothed, have access to services necessary for health, education, and well-being, and enjoy the rewards of their labor in dignity and in freedom. ${ }^{21}$

The Conference also approved a 'Declaration of the Social Principles of America' which called on every country in the region to adopt social legislation on a scale not lower than that indicated in ILO conventions, including the recognition of the right of workers to organize, bargain collectively, and to strike. ${ }^{22}$ This Declaration was premised on the axiom that 'man must be the center of interest of all efforts of peoples and governments,' a thought that returned like a comet 50 years later at the United Nations (UN) Copenhagen Summit. ${ }^{23}$ The extensive language on worker rights negotiated at Mexico City is astonishing, and may be explainable in part by the fact that some of the national delegations contained nongovernmental advisors from labor, social, and educational movements. ${ }^{24}$ This inclusive form of participation was not used in subsequent conferences, and is not a feature of the current FTAA negotiations. $^{25}$

Latin American attention to the problem of unfair labor competition was brought forward into the UN Conference on Trade and Employment. This Conference drafted the Charter of the International Trade Organization (ITO), but it did not go into force. As one of the drafters has

\footnotetext{
${ }^{21}$ Final Act of the Inter-American Conference on Problems of War and Peace (Pan American Union, 1945), Res. LI, 92, at 94-96. This was a conference of wartime allies that excluded Argentina because of its neutrality.

${ }^{22}$ Final Act, supra note 21, Res. LVIII, 102, at 104-105. This was three years before the adoption of the ILO Convention on Freedom of Association and the Right to Organise (No. 87).

${ }^{23}$ Compare: 'To this end, we will create a framework for action to: (a) Place people at the centre of development and direct our economies to meet human needs more effectively;...' World Summit for Social Development, Copenhagen Declaration on Social Development, 12 March 1995, UN Doc. A/CONF.166/9, para. 26(a).

${ }^{24}$ Inman, supra note 4, at 212. The nongovernmental advisors also sought to influence the negotiations on trade. For example, the U.S. government's proposal for reciprocal tariff reductions was opposed by the Mexican trade unions who argued that the United States had relied upon tariffs to protect domestic industries during its own industrial development. Id. at 215.

${ }^{25}$ Several years ago, Brazil sought a role for labor representatives in national delegations to the FTAA talks, but gave up after opposition by the Clinton Administration and other governments. Kevin G. Hall, 'Brazil Drops Demand for Labor at Trade Talks,' Journal of Commerce, 15 May 1997, 5A.
} 
chronicled, there was a demand from a number of Latin American countries that each government should be relieved of trade obligations toward countries having lower labor conditions. ${ }^{26}$ Although this effort to adopt a labor escape clause failed, the ensuing ITO Charter did include a provision on fair labor standards. ${ }^{27}$

Labor has always been an OAS issue. The OAS Charter was drafted in 1948 at the Ninth Pan American (Bogotá) Conference. ${ }^{28}$ The original OAS Charter contained two articles on Social Standards, one of which sought 'respect for freedom of association and for the dignity of the worker. ${ }^{29}$ The current Charter contains more elaborate provisions regarding labor. ${ }^{30}$ For example, the governments have agreed to make the greatest possible efforts to harmonize social legislation of the developing countries, so that the rights of workers will be equally protected, and in order to facilitate the process of Latin American and Caribbean integration. In addition, the OAS spearheaded the American Convention on Human Rights of 1969, which features several labor rights provisions. ${ }^{31}$

\footnotetext{
${ }^{26}$ Clair Wilcox, A Charter for World Trade (MacMillan, 1949), at 139.

${ }^{27}$ Havana Charter for an International Trade Organization, March 1948, Art. 7, available at http://www.worldtradelaw.net. Susan Ariel Aaronson, Taking Trade to the Streets. The Lost History of Public Efforts to Shape Globalization (University of Michigan Press, 2001), at 52-53; Elissa Alben, 'GATT and the Fair Wage: A Historical Perspective on the Labor-Trade Link,' 101 Columbia Law Review 1410, at 1427-1441 (2001) (reviewing the negotiations and efforts to implement them).

${ }^{28}$ This Conference also approved the American Declaration of the Rights and Duties of Man that contains several provisions on labor and employment. See http://www1.umn.edu/humanrts/oasinstr/zoas2dec.htm. Among its provisions is the statement that 'It is the duty of every person to work, as far as his capacity and possibilities permit, in order to obtain the means of livelihood or to benefit his community.' Id. Art. XXXVII.

${ }^{29}$ Charter of the OAS, 30 April 1948, 119 UNTS 3, Arts. 28, 29.

${ }^{30}$ Charter of the OAS, available at http://www.oas.org, Arts. 34(g), 45, 46.

${ }^{31}$ See American Convention on Human Rights, 22 November 1969, available at http://www.cidh.oas.org/Basicos/basic2.htm, Arts. XIV, XVI, XXII. Robert F. Drinan, The Mobilization of Shame (Yale, 2001), at 112-117 (discussing the Inter-American human rights regime).
} 
The OAS has been very active in the period from 1994 onward. One key landmark was the adoption, on September 11, 2001, of the Inter-American Democratic Charter. Declaring that 'the peoples of the Americas have a right to democracy,' the Charter contains numerous important commitments and statements, including that the strengthening of democracy 'requires the full and effective exercise of workers' rights and the application of core labor standards' recognized in the ILO. $^{32}$

So far, my study has examined the labor facets of Inter-American political relations, but two other ongoing streams of regional labor cooperation should be considered. One has been carried out under the auspices of the ILO. The other operates within the framework of the Inter-American system.

One interesting footnote of ILO history is that the opening session of its inaugural 1919 conference was held in the ornate Hall of the Americas at the Pan American Union building in Washington, D.C. The Executive Officer of the Union welcomed the ILO, and expressed hope that the 30 years of Pan American cooperation would inspire the ILO. ${ }^{33}$ At the 1919 Conference, there were delegations from 16 Latin American countries. ${ }^{34}$

Since 1936, there have been 15 Labour Conferences of the American States. Like all ILO activities, these were tripartite conferences with national participation by governments, workers, and employers. While many of the resolutions adopted were trained on industrial relations, some also covered international trade policy. For example, in 1939, a resolution on Economic and Financial

\footnotetext{
${ }^{32}$ Inter-American Democratic Charter, available at http://www.oas.org/charter/docs, Arts. 1, 10. The first initiative to promote democracy in Latin America may have been the effort of Pedro Felix Vicuña in 1837. Kathryn Sikkink, 'Reconceptualizing Sovereignty in the Americas: Historical Precursors and Current Practices,' 19 Houston Journal of International Law 705, at 713 (1997).

${ }^{33}$ League of Nations, International Labor Conference, First Annual Meeting (GPO, 1920), at 11-12.

${ }^{34}$ Jef Rens, 'Latin America and the International Labour Organisation,' 80 International Labour Review 1, at 2 (1959).
} 
Cooperation observed that 'an increase in international trade activity is calculated to promote an improvement in standards of life...,' and also recommended that 'credit arrangements concluded between nations of the American continent should make provision for the effective enforcement of fair labour standards upon all work financed in virtue of such agreements. ${ }^{35}$ The 1946 Conference approved a resolution on Vocational Training that went well beyond the existing ILO recommendation in addressing the need for 'training and retraining of adult workers. ${ }^{36}$ The 1949 Conference approved a resolution on the Social Aspects of Economic Development that called for measures to promote the expansion of markets by the development of international trade, and urged the ILO to cooperate with the Economic Commission for Latin America and the International Trade Organization. ${ }^{37}$ The resolution further stated that technical assistance directed to the social aspects of economic development should form an integral part of any program of technical assistance furnished through international organizations. In a survey of the first 40 years of ILO work in Latin America, Jef Rens concluded that ILO conventions and technical assistance had an important influence on national law. ${ }^{38}$

\footnotetext{
${ }^{35}$ Second Labour Conference of the American States which are Members of the International Labour Organisation (ILO, 1941), Res. XII, 262, at 263.

${ }^{36}$ Third Labour Conference of the American States which are Members of the International Labour Organisation (ILO, 1946), Res. 1, 270, at 274. Compare to the ILO Vocation Training Recommendation (No. 57), 1939.

${ }^{37}$ Fourth Labour Conference of American States Members of the International Labour Organisation (ILO, 1951), Res. 7, 263, at 268.

${ }^{38}$ Rens, supra note 34 . He quotes a Colombian government official as saying in 1933 that legislative provisions for the protection of workers' rights in Latin America 'is due exclusively to Geneva'. Id. at 19.
} 
The second stream of labor cooperation is transgovernmental. ${ }^{39}$ In 1963, the labor ministers in the Americas began to hold conferences of their own as an outgrowth of the Alliance for Progress. The 1963 Conference agreed on several principles, including that financial aid and trade policy should be integrated, and that measures be taken to stabilize Latin America's foreign exchange earnings. Another principle enunciated was that there can be no effective economic and social development planning unless the legitimate rights of labor are recognized..$^{40}$ At the Fourth Conference in 1972, the labor ministers called attention to the 'gravity of the social problems affecting American countries and the urgency of social development that goes beyond the criteria of the economists. ${ }^{41}$ The Conferences over the next 20 years left little record.

Labor cooperation was reinvigorated by the 1st Summit of the Americas in 1994 and by the initiation of the FTAA process. These two developments breathed new relevance into the conferences of the Ministers of Labor by giving them an additional mission - to provide a channel for labor concerns outside of trade negotiations. The $10^{\text {th }}$ Labor Conference, held in 1995, set up a working group to prepare a submission to the Ministers of Trade. ${ }^{42}$ This declaration was presented to the 3rd FTAA ministerial in 1997. One of the suggestions made was that the FTAA should introduce 'a social dimension that guarantees, as a minimum, respect for basic labor standards.... ${ }^{43}$ In 1998, the 2nd Summit of the Americas adopted a Plan of Action stating that the governments would exchange

\footnotetext{
${ }^{39}$ The cooperation on labor is not formally part of the OAS. Similarly, the FTAA negotiations do not belong to the OAS. Based on interviews with OAS officials Eduardo Mendoza and José Manuel Salazar.

${ }^{40}$ Inter-American Conference of Ministers of Labor on the Alliance for Progress (OAS, 1963), at 4849.
${ }^{41}$ Fourth Conference, Final Act, OAS Doc. Ser.C/VI.16.4, November 1972, para. 5.
${ }^{42}$ The labor minister conferences benefit from two advisory committees, from trade unions and from business.

${ }^{43}$ Declaration of the Tenth Inter-American Conference of Ministers of Labor Presented at the Meeting of Ministers of Trade, Belo Horizonte, Brazil, May 1997, available at http://www.sice.oas.org/FTAA/Belo/Minis/Cotpal_e.asp.
} 
informational materials regarding their labor legislation and further secure the observance and promotion of internationally recognized core labor standards. ${ }^{44}$ Shortly thereafter, the governments held the $11^{\text {th }}$ Labour Conference which stated that the policies that form the basis of economic growth, including free international trade, should be designed in a way that produces more jobs consistent with internationally-recognized core labor standards. ${ }^{45}$ In 2001, the 3 rd Summit of the Americas adopted a Plan of Action with broad but general language on 'Labor and Employment.' Shortly thereafter, the $12^{\text {th }}$ Labour Conference established two working groups - one on the Labour Dimensions of the Summit of the Americas Process and the other on Building Capacity of Labour Ministries. ${ }^{46}$ The $13^{\text {th }}$ Labor Conference of 2003 adopted the Salvador Declaration which emphasizes the importance of considering the social and labor components of hemispheric integration during all stages of the FTAA negotiations process. ${ }^{47}$

Notwithstanding the repeated efforts of the labor ministers to signal that labor concerns should be addressed in FTAA talks, the most recent declaration adopted by the FTAA trade ministers (in November 2003) omits any labor dimension for the negotiations. ${ }^{48}$ So far, no government has made a substantive labor proposal for the FTAA.

\footnotetext{
${ }^{44}$ Second Summit of the Americas, Plan of Action, April 1998. This and other Summit documents not specifically referenced here are available at http://www.summit-americas.org.

${ }^{45}$ Declaration of Viña del Mar, 21 October 1998, OAS Trabadjo/doc.5/98 Rev. 2, para. 4.

${ }^{46}$ Declaration and Plan of Action of Ottawa, 2001, available at http://www.oas.org/udse/ingles2004/frameset.html.

${ }^{47} 13^{\text {th }}$ Inter-American Conference of Ministers of Labor, Salvador Declaration, 26 September 2003, para. 22, available at http://www.summit-americas.org/Quebec-Labor/labor-eng.htm.

${ }^{48} 8^{\text {th }}$ FTAA Ministerial Declaration, November 2003, available at http://www.ftaa-alca.org. This Declaration expresses appreciation to the labor ministers for their input. An earlier FTAA ministerial declaration had stated that most ministers recognize that the issues of environment and labor should not be utilized as conditionalities nor be subject to disciplines. $6^{\text {th }}$ FTAA Ministerial Declaration, April 2001, Annex I, para. 1, available at http://www.ftaa-alca.org/Ministerials/BA/BA_e.asp.
} 
In summary, this historical glance back provides context for thinking about the labor and trade connection in the Western Hemisphere. Achieving an FTAA would be the fruition of efforts for trade integration that began in the early $19^{\text {th }}$ century. Inter-American attention to employment and labor extends back to the early $20^{\text {th }}$ century, and the principle that there are common labor norms is well embedded. The idea that core labor standards should undergird trade liberalization has been part of trade discourse in the Americas since the 1940s. Nevertheless, consideration of labor as part of the FTAA negotiation has been resisted by nearly all countries, which have instead preferred to address labor via a network of labor ministries. ${ }^{49}$ The inclusion of labor within an FTAA would be a dead letter were it not for the fact that gaining provisions on labor is one of the statutory trade negotiation objectives of the United States. ${ }^{50}$

\section{How Free Trade Agreements Address Labor}

Any forthcoming labor dimension to the FTAA will be influenced by the existing law and practice of free trade agreements in the region. Part 2 will provide an overview of that varied experience. Some treaties, such as the recent Free Trade Agreement between Chile and South Korea, completely omit labor. ${ }^{51}$ Yet many trade agreements do include labor, and this practice began with the North American Free Trade Agreement (NAFTA) which was accompanied by a side agreement on labor. The three parties in NAFTA are Canada, Mexico, and the United States.

The experience so far is summarized in Table 1, 'Comparison of Key Labor Features of Selected Inter-American Free Trade Agreements.' The agreements are listed chronologically from

\footnotetext{
${ }^{49}$ José Manuel Salazar-Xirinachs and Jorge Mario Martínez-Piva, 'Trade, Labour Standards and Global Governance: A Perspective from the Americas,' in Stefan Griller (ed), International Economic Governance and Non-Economic Concerns (Springer Verlag Wien, 2003), 315, at 336, 354.

${ }^{50} 19$ U.S.C. § 3802(b)(11). See Robert B. Zoellick, 'When Trade Leads to Tolerance,' New York Times, 12 June 2004, A13 ('The United States is the only nation pressing to include enforceable labor and environmental protections in its trade agreements.').

${ }^{51}$ Free Trade Agreement between the Republic of Korea and the Republic of Chile, 15 February2003, available at http://www.sice.oas.org/Trade/Chi-SKorea_e.
} 
left to right. One conclusion that can be drawn from Table 1 is that there is no optimal treatment of labor in the sense of an agreement that is more progressive than the others in every way. The purely American agreements do more on transparency and access to courts, while the agreement with the European Community is more attentive to public participation and discourse. The only agreement to create an international commission to promote cooperation is the North American Agreement on Labor Cooperation (NAALC) in 1993. The other agreements promote cooperation through meetings of national officials.

As Table 1 shows, none of the provisions on labor is subject to adjudication except for the obligation that governments avoid a trade-related persistent pattern of failure to effectively enforce national labor law. The obligation to enforce national labor law is supervised through state-to-state dispute settlement rather than by giving victims a right of action. If a complaining government lodges a dispute and wins, the scofflaw government would be expected to improve its national enforcement and if it does not, a monetary assessment can be imposed. Two of the agreements provide for a trade sanction - a withdrawal of trade agreement benefits - to promote compliance.

A requirement to enforce national law is a puzzling objective in an international agreement. The traditional approach in conventional international law is to promote a convergence and uplifting of national law. Certainly, that is the stance taken by the ILO since $1919 .^{52}$

The idea of using an international agreement to supervise the enforcement of national labor law began with the NAFTA side agreement in 1993. This agreement was orchestrated by the Clinton Administration which often pursued minimalist approaches to policy challenges. The proposition that Country A has an interest in whether Country B enforces its national labor law, irrespective of the content of Country B's labor law, is hardly self-evident. Certainly, one can imagine situations where

\footnotetext{
${ }^{52}$ Nicolas Valticos, 'Droits de l'Homme et Droits du Travail sur le Plan International,' in Droits Syndical et Droits de l'homme à l'aube du XXIe Siecle: Mélanges en l'honneur de Jean-Maurice Verdier (Dalloz, 2001), at 473. See also ILO Convention Concerning Night Work in Bakeries (No. 20), 8 June 1925, Art . 5 (calling on parties to ensure that its prohibition 'is effectively enforced').
} 
B's law would be so repugnant to A that A might not want B to enforce it. B's law might also be inefficiently rigid, and so B may have a good reason not to enforce it. Many governments allow outdated laws to remain on the books.

Nevertheless, one should not controvert the possibility of constructive results from a process of reciprocal review of national enforcement. The actual results of the process need to be examined. No empirical study has come to my attention of changes in the quality of labor law enforcement in North America over the past 10 years. But data are available about the implementation of the side agreement. ${ }^{53}$

The NAFTA labor side agreement has been in effect since January 1994, and in over ten years, no government has brought a case against another government's lack of enforcement of the covered labor laws. Many informed observers have concluded that the NAFTA parties all live in

\footnotetext{
${ }^{53}$ No consensus exists about the value of the NAFTA labor agreement. Many analysts have commended it: See Frederick M. Abbott, 'The North American Integration Regime and its Implications for the World Trading System,' J.H.H. Weiler (ed), The EU, The WTO and the NAFTA. Towards a Common Law of International Trade (Oxford, 2001), 169, at 196-197; Ronald G. Ehrenberg, Labor Markets and Integrating National Economies (Brookings, 1994), at 98-99; William B. Gould IV, 'Labor Law for a Global Economy: The Uneasy Case for International Labor Standards,' in Robert J. Flanagan and William B. Gould IV (eds), International Labor Standards (Stanford University Press, 2003), 81, at 104-105; Marley S. Weiss, 'Two Steps Forward, One Step Back - Or Vice Versa: Labor Rights under Free Trade Agreements from NAFTA, Through Jordan, via Chile to Latin America, and Beyond,' 37 University of San Francisco Law Review 689, at 700707 (2003) (discussing the NAFTA 'innovation' of transposing domestic law into a trilateral agreement).
}

Others analysts have criticized the agreement: See 'Labor Agreement Process Criticized for Failure to Protect Workers' Rights,' BNA Daily Report for Executives, 2 April 2004, A-10; William Dymond, 'Core Labour Standards and the World Trade Organization: Labour's Love Lost,' 8 Canadian Foreign Policy, Spring 2001, 99, at 102; Pharis J. Harvey \& Bama Athreya, 'Developing Effective Mechanisms for Implementing Labor Rights in the Global Economy,' Workers in the Global Economy (Cornell University School of Industrial and Labor Relations, 2001), 1, at 13-16; Laura Okin Pomeroy, 'The Labor Side Agreement under the NAFTA: Analysis of its Failure to Include Strong Enforcement Provisions and Recommendations for Future Labor Agreements Negotiated with Developing Countries,' 29 George Washington Journal of International Law and Economics 769 (1996); Katherine Van Wezel Stone, 'Labor and the Global Economy: Four Approaches to Transnational Labor Regulation,' 16 Michigan Journal of International Law 987, at 1010 (1995) (noting that it is difficult to imagine any situation in which the side agreement's procedures for obtaining labor law enforcement would apply). 
glass houses with regard to labor rights, and so would be uninterested in throwing stones at the others. For that reason, the three governments are also uninterested in amending the side agreement to allow individuals to lodge complaints to an international tribunal.

The side agreement does allow individuals to send communications about national enforcement problems, and 28 have been sent. ${ }^{54}$ Little has happened as a result, however, except for some joint statements and remedial seminars. Of course, the fact that the enforcement provisions have proved a nullity does not mean that the side agreement is unsuccessful. Overall, the experiment has proved useful in creating an international commission to promote North American labor cooperation.

Unfortunately, that institutional centerpiece was omitted from the U.S.-Chile Free Trade Agreement. All that free trade agreement (FTA) does is to copy the problematic enforcement provisions from the NAFTA side agreement. At the time of the NAFTA negotiation, the ILO Declaration on Fundamental Principles and Rights at Work did not yet exist. ${ }^{55}$ The U.S.-Chile FTA takes note of the Declaration, but does not mandate that governments follow it. ${ }^{56}$

The unratified U.S.-Central America Free Trade Agreement (CAFTA) adopts the same approach of supervising the enforcement of national law. ${ }^{57}$ Kimberly Elliott calls this the 'enforceyour-own-laws' standard, and worries that it could discourage improvements in labor law if a

\footnotetext{
${ }^{54}$ Commission for Labor Cooperation, Summary of Communications, March 2004, available at http://www.naalc.org/english/naalc.shtml.

${ }^{55}$ For a discussion of the 1998 Declaration, see Kari Tapiola, 'The ILO Declaration on Fundamental Principles and Rights at Work and its Follow-up,' in Roger Blanpain (ed), Multinational Enterprises and the Social Changes of the XXIst Century (Kluwer, 2000), 9.

${ }^{56}$ The U.S.-Chile FTA calls on governments to 'strive to ensure' that municipal law is consonant with the ILO Declaration, but this provision is not subject to dispute settlement. U.S.-Chile Free Trade Agreement, 6 June 2003, available at http://www.ustr.gov, Art. 18.1.

${ }^{57}$ Central America Free Trade Agreement (CAFTA), 28 May 2004 (not in force), available at http://www.ustr.gov, Chap. 16.
} 
government feels unable to enforce even its existing laws. ${ }^{58}$ Senator John F. Kerry has pledged to revise the CAFTA's labor chapter if elected President. ${ }^{59}$ Unlike NAFTA, CAFTA does not set up a labor commission.

The absence of aspirations for labor law harmonization in Inter-American FTAs can be contrasted with the pro-active approach taken with other economic objectives. This disparity is demonstrated by Table 2, a synoptic 'Comparison of Major Features of the North American Free Trade Agreement and Side Agreements.' NAFTA's provisions on market access, investment, and intellectual property commit the governments to follow NAFTA norms as prescribed or as incorporated by reference from other international treaties. For example, the commitment for intellectual property is not merely to enforce each country's own national law. Instead, the governments seek much deeper harmonization, by obliging each government to give rights to private parties in specified forms of intellectual property. By contrast, for labor and the environment, the NAFTA regime seeks only to reinforce the existing national law rather than to improve it. ${ }^{60}$ Referring to this double standard in U.S. trade agreements, Kimberly Elliott and Richard Freeman observe that 'If capital needs international protection from potentially corrupt and rapacious government officials, surely so does labor. ${ }^{91}$ The rationale for treating labor (and environment) differently from the other harmonization is not explained within the NAFTA side agreements or in

\footnotetext{
${ }^{58}$ Kimberly Ann Elliott, 'Labor Standards, Development, and CAFTA,' Institute for International Economics Policy Brief, March 2004, at 6.

${ }^{59}$ Neil King Jr., 'Kerry Would Seek Tighter Standards Governing CAFTA,' Wall Street Journal, 1 June 2004, A6.
}

${ }^{60}$ Both NAFTA side agreements contain hortatory provisions calling on parties to provide 'high levels of environmental protection' and 'high labor standards,' and to strive for improvement. North American Agreement on Environmental Cooperation (NAAEC), 14 September 1993, Art. 3; NAALC Art. 2. Furthermore, the NAALC includes a list of 'Labor Principles' that parties are committed to promote, subject to each party's own domestic labor law. NAALC Annex 1.

${ }^{61}$ Kimberly Ann Elliott and Richard B. Freeman, Can Labor Standards Improve Under Globalization? (Institute for International Economics, 2003), at 11. 
newer FTAs with that same orientation, such as the U.S.-Chile FTA. Perhaps revealing the insufficiency of the stated labor objectives of recent FTAs, U.S. Trade Representative Robert B. Zoellick has sought public credit for coaxing other countries to raise their laws during the trade negotiations. $^{62}$

The absence of any labor litigation under the NAFTA side agreement does not result from a lack of litigiousness among NAFTA's stakeholders. On the contrary, since the time that NAFTA went into force in 1994, there have been five commercial complaints brought by governments, 94 commercial complaints brought by private parties, and 35 investment complaints brought by private parties. ${ }^{63}$ Thus, a reasonable hypothesis might be that if the NAFTA labor agreement contained a meaningful discipline and a private right of action, numerous cases would have been filed.

NAFTA is not the only Inter-American trade agreement with a labor dimension. ${ }^{64}$ The Common Market of the South (Mercosur) also has given attention to social problems. The activities in Mercosur feature tripartite consultation and the collection and analysis of data. In the Andean Community, there are regular meetings of the ministers of labor.

The overall topic addressed by this study is whether the FTAA should contain rules on labor and, if so, what they ought to be. No optimal architecture exists for FTAs. Rather, the right design depends on what policymakers seek to achieve. Unless governments are willing to provide a private

\footnotetext{
${ }^{62}$ For example, Zoellick has stated that Chile repealed Pinochet-era labor laws during the course of the FTA negotiations and that Guatemala improved the implementation of labor laws in export processing zones. See Robert B. Zoellick, 'Helping Labor Through Trade,' Washington Post, 19 April 2004, A19.

${ }^{63}$ Author's tabulations of data available on 30 May 2004 from http://www.nafta-sec-alena.org and http://www.naftalaw.org.

${ }^{64}$ See American Center for International Labor Solidarity, Justice for All. A Guide to Worker Rights in the Global Economy (AFL-CIO, 2003), at 128-138; ILO, Labour Standards and the Integration Process in the Americas (2001); Marie-Claire Cordonier Segger, 'Inter-American Perspective: Sustainable Development in the Negotiation of the FTAA,' 27 Fordham International Law Journal 1118, at 1140-1156 (2004); Willi Momm (ed), Labour Issues in the Context of Economic Integration and Free Trade - A Caribbean Perspective (ILO, 1999).
} 
right of action to an international tribunal, however, no labor policy purpose is served by the current FTA approach of committing governments to enforce their own idiosyncratic labor laws. The only purpose being served by these labor provisions is to satisfy the political need of appearing to use the FTA to safeguard worker rights.

That an international commitment to enforce one's own domestic law makes little sense does not necessarily justify the alternative approach of including within an FTA an obligation to follow international labor standards. On the contrary, it would seem that if Countries A, B, C, etc. have an interest in upwardly harmonizing their labor policies, that goal might be better accomplished through a labor rather than a trade agreement. As Table 1 shows, some of the earlier Inter-American FTAs took the approach of having a separate labor agreement, but that configuration has now been abandoned (at least by the United States) in an effort to give trade agreements a holistic veneer. What seems to be driving the current U.S. effort to incorporate labor provisions into FTAs is not to achieve benefits of labor cooperation, but rather to show that trade concessions will be withdrawable should the labor commitment be violated. That logic relates to political coalition building more than to economic coherence. Part 3 of this study will discuss the economic coherence of sole labor and trade-related labor cooperation, as well as the political foundations for intergovernmental labor cooperation.

Before moving to Part 3, this lecture will address one other matter, which is the tension between regional and multilateral initiative. If countries in the Americas want to foster worker rights and improve labor standards, then why not just do that through the ILO $?^{65}$ The answer is that international labor cooperation can be pursued on a dual track — globally at the ILO and regionally

\footnotetext{
${ }^{65}$ Robert M. Stern, 'Labor Standards and Trade Agreements,' University of Michigan Discussion Paper No. 496, 2003, at 21.
} 
in various fora. The periodic ILO regional conferences are aimed at capacity building and strengthening of the multilateral system; they do not seek separate labor conventions. ${ }^{66}$

The orientation is different in the trade arena where regional efforts sometimes take the shape of preferential trade agreements. These are discriminatory regimes that may or may not be supportive of the multilateral World Trade Organization (WTO) ${ }^{67}$ In general, a regional trade agreement can never rank higher than second best to a multilateral agreement. ${ }^{68}$ The nature of trade and the need for cooperation is exactly the same in one region as in another.

By contrast, the rationale for a regional labor agreement can be stronger than for a regional trade agreement if a regional labor market exists or if a region has a distinctive pattern of industrial relations. In such instances, there may be a need for a discrete policy in one region that would not be appropriate in another region, or globally. More likely, however, the justification for including labor rules in a regional FTA will be to achieve a more balanced agreement. According to the World Commission on the Social Dimension of Globalization, '...if regional integration is to be a stepping stone towards a fairer globalization, a strong social dimension is required. ${ }^{69}$

\section{Normative Basis for International Labor Cooperation}

Part 3 discusses the conceptual underpinning of a labor dimension to the FTAA. Because labor law is so contested, this case will be constructed from the bottom up. First, I review the need

\footnotetext{
${ }^{66}$ See Rens, supra note 34 , at 6.

${ }^{67}$ See Jeffrey J. Schott, 'Free Trade Agreements: Boon or Bane of the World Trading System?' and the responses by Richard N. Cooper, Renato Ruggiero, and Guy de Jonquières, in Schott (ed), Free Trade Agreements (Institute for International Economics, 2004), at 3-33.

${ }^{68}$ For a different perspective, see Sir James Goldsmith, The Trap (Carroll \& Graf, 1993), at 43 (stating that 'We must start by rejecting the concept of global free trade and we must replace it by regional free trade.').

${ }^{69}$ World Commission on the Social Dimension of Globalization, A Fair Globalization (ILO, 2004), para. 327.
} 
for national labor law. Second, I explain the need for international labor law. Third, I consider whether labor objectives should be sought in a trade versus a labor agreement.

\section{A. Why National Labor Law?}

National labor law is aimed at achieving three distinct objectives - correcting market failure, protecting against government abuse, and enhancing equity. These concerns exist at the national level, and would underlie labor law even in an imaginary world where countries shun transborder economic intercourse. ${ }^{70}$ In the simplest vertical model, the government regulates the private actors. In a vertical federal model, there are also allocations of authority between subnational governments and the national government.

Perhaps the most compelling reason for labor law is to correct market failures. ${ }^{71}$ Such failures include: (1) poor information about workplace hazards, (2) imperfect competition in labor markets, (3) inadequate capital markets which make it hard for workers to obtain education, training, and to relocate, (4) coercion of certain workers, such as children, and (5) an undersupply of quasi-public goods, such as labor-management harmony. Another problem is high unemployment which might be considered a labor market failure in that there is a seller of labor without a buyer. Yet high unemployment also constitutes a government failure. ${ }^{72}$ The unemployment may be caused by poor macroeconomic performance, excessive taxes or regulations on employment, or an economy inhospitable to new investment.

\footnotetext{
${ }^{70}$ Contrasting autarkic with interdependent economies is helpful for analytical purposes, but there have been few instances in modern experience of autarkic economies.

${ }^{71}$ Compare OECD, Trade and Labour Standards, A Review of the Issues (OECD, 1995) at 16 (stating that '...the literature on the labour standards question has not gone very far toward specifying what market failure is being corrected').

${ }^{72}$ Wallace McClure, World Prosperity As Sought Through the Economic Work of the League of Nations (Macmillan, 1933), at 65 ('The most vital national economic interest of every country is that its people shall always be efficiently at work.').
} 
A second purpose of labor law is to protect individuals from mistreatment by government officials. The most serious abuses are forced labor, infringement on freedom of association, and discrimination against certain groups like indigenous persons and women. The prohibition of such behavior is often coupled with laws recognizing individual rights to be free from such practices. Governmental respect for those rights is a precondition for controlling similar abuses by private actors.

A third reason for labor law is to achieve the national conception of justice chosen through democratic processes. Labor markets are known to have inequalities in bargaining power between workers and employers. ${ }^{73}$ This asymmetry is not necessarily a market failure - as markets are not established to achieve equity — but it is a social problem for which governments use law to remedy. For example, national labor law may provide a right to organize a labor union and to bargain collectively. Governments might also mandate a minimum quality of working conditions as a way to achieve income redistribution.

\section{B. Why International Labor Law?}

Why do governments cooperate, and perceive a need to cooperate on labor issues? ${ }^{74}$ The question is an important one, and has not received the attention it deserves. ${ }^{75}$ Back in 1942 , the InterAmerican Juridical Committee acknowledged that the realization of labor objectives 'is primarily the task of each separate State,' but then postulated that 'only by parallel international action can they be

\footnotetext{
${ }^{73}$ Lord Wedderburn, 'Common Law, Labour Law, Global Law,' in Bob Hepple (ed), Social and Labour Rights in a Global Context (Cambridge, 2002), 19, at 27.

${ }^{74}$ The question is somewhat ahistoric. The movement to enact national labor legislation does not significantly predate the movement to negotiate international conventions. See Ernest Mahaim, 'The Historical and Social Importance of International Labor Legislation,' in James T. Shotwell (ed), The Origins of the International Labor Organization (Columbia University Press, 1934), Vol. I, 3 , at 5.

${ }^{75}$ Jan Klabbers, An Introduction to International Institutional Law (Cambridge, 2002), at 29 (noting that the explanation of international cooperation is one of the central questions of the social sciences).
} 
adequately secured. ${ }^{, 76}$ The Committee, however, did not explain why such parallel action proves useful. ${ }^{77}$ This lecture seeks to do so.

In an autarkic economy, each nation would set its own labor law based solely on internal considerations; yet in an interdependent world economy, foreign conditions will also shape national welfare ${ }^{78}$ Typically, the effects of foreign conditions are transmitted through the market via crossborder trade and investment. Yet there are also some external effects that are transmitted physically. ${ }^{79}$ For example, forced labor in Country A can send refugees in Country B; high unemployment in Country B can send migrants to Country C. Country D might be concerned about trafficking in women or children from Country E into D.

Before discussing the market-oriented factors and other rationales for international labor law, I should note that all of these explanations are state-centric. In other words, they try to explain why a government would seek coordination of labor law with another government, and would select modalities between soft norms and hard rules. Because hard rules restrict national autonomy, there is presumably a logic as to why a government would bind itself into such an arrangement. Yet sometimes, a clear logic may not be evident.

\footnotetext{
${ }^{76}$ See text accompanying supra note 20.

${ }^{77}$ The proposition that the international economy necessitates international labor rules is often asserted without much explanation. For example, see J.F. Rischard, High Noon (Basic Books, 2002), at 146 (stating that 'the greater interdependence between countries created by the new world economy makes it more urgent to find a stronger and broader framework for labor rules than has evolved so far').

${ }^{78}$ See Chair's Conclusions, G8 Labor and Employment Ministers Conference, December 2003, para. 4, available at http://www.g7.utoronto.ca ('Labor market development is shaped by many factors at both the domestic and international levels.'); World Commission on the Social Dimension of Globalization, supra note 69, para. 493 ('Today, countries cannot achieve employment goals on their own.').

${ }^{79}$ Compare Andrew T. Guzman, 'Trade, Labor, Legitimacy,' 91 California Law Review 885, at 892 (2003) (stating that 'poor labor standards have virtually no harmful cross-border effects').
} 
In reality, national policy may not be dictated by a rational sovereign. Instead, political processes may be driven by volitions of elites and technocrats, and by pressures from interest groups. Thus, putting forward conceptual reasons why unitary governments might cooperate in labor policy may overemphasize top-down decisionmaking, and underemphasize the economic and social actors that animate the political process. ${ }^{80}$ Explanations of why states cooperate to liberalize trade often get stuck on the same flawed top-down orientation.

A central explanation for international labor cooperation is to prevent inefficient competition for trade and investment. This explanation is now called 'race to the bottom. ${ }^{81}$ To wit, each government would like to propound good labor standards, but cannot because of competition against countries with lower labor standards. The optimal policy for each country of enjoying high standards is replaced by mutual defection, with all countries lowering their standards. The same story can be told in a less state-centric fashion by recounting the pressure that multinational corporations allegedly place on governments to lower their standards in order to attract or maintain investment. ${ }^{82}$

The traditional solution to this problem is that governments should agree to harmonize their core labor standards, or agree on minimum standards. This is mutually-supportive cooperation in the sense that a high labor standard in one country can help its trading partner maintain its own high standard. A bilateral agreement would make no sense if either of the two governments did not want the high standard in the first place. Mutually-supportive cooperation can be distinguished from

\footnotetext{
${ }^{80}$ See Richard E. Feinberg, 'The Political Economy of the United States' Free Trade Arrangements,' 26 The World Economy 1019, at 1037 (2003) ('A unitary actor model cannot explain contemporary US trade policy.').

${ }^{81}$ Brian A. Langille, 'Eight Ways to Think about International Labour Standards,' 31 Journal of World Trade, August 1997, 27, at 37-43. See also Christoph Scherrer, 'The Pros and Cons of International Labour Standards,' in Norbert Malanowski (ed), Social and Environmental Standards in International Trade Agreements (Westfälisches Dampfboot, 1997), 32, at 35 (stating that the threat to competitiveness is the reason why social standards have to be negotiated internationally).

${ }^{82}$ See Elliott and Freeman, supra note 61, at 23 (noting study of pressure placed on the United States).
} 
essential cooperation which occurs when solving a problem requires joint action (e.g., cleaning up pollution in a border river).

The first champion of international labor law on mutually-supportive grounds was the SwissAlsatian social reformer Daniel Legrand. In 1840, Legrand began calling for action to respond to labor 'abuses arising under the influence of competition through negotiations between the governments of industrial countries. ${ }^{83}$ Legrand's lobbying technique was to write a letter to a conference of the German customs union, the Zollverein, and then get the Prussian government to circulate the letter. No negotiations were undertaken by the Zollverein. Nevertheless, this episode has historical importance in showing that the earliest effort to secure international labor cooperation was linked to a trade agreement. Legrand worked nearly 20 years to promote international labor legislation, and his bust graces the lobby of the Geneva building housing the WTO.

The view that trade competition can undermine national labor standards has maintained its salience for over 160 years. In 1919, the preamble to Part XIII (Labour) of the Treaty of Versailles famously intoned that 'the failure of any nation to adopt humane conditions of labour is an obstacle in the way of other nations which desire to improve the conditions in their own countries. ${ }^{84}$ As Herbert Feis explained in 1927, the ILO was set up to help overcome the downward pressure on labor

\footnotetext{
${ }^{83}$ John W. Follows, Antecedent of the International Labour Organization (Oxford, 1951), at 28, 31 , 42, 201. Before Legrand, there were others who had recognized the potential merit of international labor legislation, including Charles Hindley (then a British businessman, later a noted parliamentarian) and Jérôme Blanqui (a French economist).

${ }^{84}$ Treaty of Versailles, 28 June 1919, 112 BFSP 1, Part XIII preamble.
} 
standards from international competition. ${ }^{85}$ Similar explanations for international labor standards were offered in succeeding decades. ${ }^{86}$

The question of whether international competition presents a significant obstacle in reality was being debated by the 1920 s. $^{87}$ Comprehensive empirical analysis did not begin until the mid1990s, when a study by the Organisation for Economic Co-operation and Development (OECD) found no evidence that countries with low core labor standards enjoy better global export performance than countries with high standards. ${ }^{88}$ Yet the fact that countries with high standards perform well in trade and economic growth does not mean that governments act accordingly. Governments may act irrationally. Or governments may be cowed by threats from multinational firms to relocate unless the government lowers its labor standards. Jagdish Bhagwati has pointed out that 'the evidence suggests that multinationals, generally speaking, do not go streaking to where labor rights are ignored or flouted. ${ }^{, 89}$ Yet even so, a government may still worry about the possibility that

\footnotetext{
${ }^{85}$ Herbert Feis, 'International Labour Legislation in Light of Economic Theory,' 1927, reprinted in Werner Sengenberger and Duncan Campbell (eds), International Labour Standards and Economic Interdependence (International Institute for Labour Studies, 1994), 30, at 35.

${ }^{86}$ See, e.g., Miroslav Jirásek, Principles of the Old and New Organization of the World, A Study in International Law (Melantrich, 1945), at 195-96.

${ }^{87}$ See, e.g., Paul Perigord, The International Labor Organization (D. Appleton and Company, 1926), at $41-42$.

${ }^{88}$ OECD, International Trade and Core Labour Standards (OECD, 2000), at 33. See also Toke Aidt and Zafiris Tzannatos, Unions and Collective Bargaining (World Bank, 2002), at 4 (noting that comparative studies reveal little systematic difference in economic performance between countries that provide for freedom of association and the right of collective bargaining, and those that do not); ILO, Report of the Director-General, Organizing for Social Justice, 2004, para. 50 ('A growing body of evidence suggests that freedom of association and the right to collective bargaining contribute to improving economic and trade performance and do not have the negative effects predicted by some economic theorists.'), available on ILO website.

${ }^{89}$ Jagdish Bhagwati, In Defense of Globalization (Oxford, 2004), at 130.
} 
such a loss of investment could happen. As Brian Langille has observed, the threat of divestment may be much more important in labor relations than is evident in actual investment data. ${ }^{90}$

Fairness is another motivation for international labor standards. The fairness argument is related to, yet separable from, the efficiency argument that international competition constrains the proper setting of national labor standards. The fairness concern is that countries with high labor standards should not have to compete against countries with low standards. ${ }^{91}$ This concern has been voiced against free trade for over 150 years, and despite its incoherence - because unfairness is so subjective $^{92}$ - the fairness argument remains prominent today.

The reason why the claim of unfair trade stemming from sweated labor cannot be debunked is that the quest for fairness is a leitmotif of contemporary trade policy. Because current WTO rules seek to protect producers against injurious dumping and subsidies, ${ }^{93}$ no way exists in principle to rule out parallel concerns about fairness to workers. ${ }^{94}$ Brian Langille said it well: 'Fair trade is free trade's destiny. ${ }^{95}$

\footnotetext{
${ }^{90}$ Langille, supra note 81, at 43. See also Terry Collingsworth, 'American Labor Policy and the International Economy: Clarifying Policies and Interests,' 31 Boston College Law Review 31, at 45 (1989) (discussing threats to relocate).

${ }^{91}$ Rafael Caldera, '75 Years of ILO,' in Visions of the Future of Social Justice: Essays on the Occasion of the ILO's 75 ${ }^{\text {th }}$ Anniversary (ILO, 1994), 55, at 57 (stating that 'Competition in international trade is unfair if it is based on a labour force that is ill-paid.').

${ }^{92}$ Michael J. Trebilcock, 'International Trade and International Labour Standards: Choosing Objectives, Instruments, and Institutions,' in International Economic Governance and Non-Economic Concerns, supra note 49, 289, at 294-296 (explaining why the fairness argument is indeterminate).

${ }^{93}$ Douglas A. Irwin, Free Trade Under Fire (Princeton, 2002), at 111-128 (discussing subsidies and dumping).
}

${ }^{94}$ OECD, Regional Integration and the Multilateral Trading System (OECD, 1995), at 22 (noting that trade liberalization agreements can no longer be concluded without taking account of sensitivities to environmental and social dumping).

${ }^{95}$ Brian Alexander Langille, 'General Reflections on the Relationship of Trade and Labor (Or: Fair Trade Is Free Trade's Destiny), in Jagdish Bhagwati and Robert E. Hudec (eds) Fair Trade and Harmonization (MIT Press, 1996), Vol. 2, 231, at 236. 
Another problem with the unfairness claim is that Country A may have a valid reason to have a lower labor standard than Country B, and, furthermore, to use its labor standard as a way to compete against B. Deciding when regulatory labor competition is appropriate is a difficult challenge, particularly in a world in which worker exit (or more exactly, immigration) is sharply constrained. ${ }^{96}$ An international harmonization of standards may not be better than continued diversity. ${ }^{97}$

The alleged unfairness of trade on labor grounds has long been used as a reason to block imports. In the $19^{\text {th }}$ century, the concern was competition against 'pauper labor' or 'cheap labor.' In the 1920 s, the term 'social dumping' was applied to trade based on low labor conditions. ${ }^{98}$ After World War II, when governments sought to establish a trading system, there were proposals to link market access to the level of labor standards. As noted above, several Latin American countries sought a labor escape clause, but this effort was resisted by the United States and others. ${ }^{99}$

A more refined version of the unfairness argument arose during the planning for the European common market. In 1956, the ILO established a Group of Experts to examine the social aspects of European integration. Among the Group's recommendations was that if a subset of countries agreed on the need to introduce some improvement in social or labor conditions, but, nevertheless, a

\footnotetext{
${ }^{96}$ See David Charny, 'Regulatory Competition and the Global Coordination of Labor Standards,' 3 Journal of International Economic Law 281 (2000) (discussing regulatory theory); Simon Deakin, 'Two Types of Regulatory Competition: Competitive Federalism Versus Reflexive Harmonisation,' 2 Cambridge Yearbook of European Legal Studies 231, at 233 (1999); Gijsbert van Liemt, 'International Trade and Workers' Rights,' in Brian Hocking and Steven McGuie (eds), Trade Politics: International, Domestic and Regional Perspectives (Routledge, 1999), 111, at 113 (discussing labor immobility).

${ }^{97}$ For an early skeptical view of harmonization, see Leonard S. Woolf, International Government 320 (Brentano's, 1916).

${ }^{98}$ See Report and Proceedings of the World Economic Conference, May 1927, League of Nations Doc. C.356.M.129, 1927, Vol. II, at 100-101.

${ }^{99}$ See text accompanying supra note 26.
} 
minority of countries were to hold out against doing so, then a country whose interest was injured might be authorized to take steps to protect itself against competition from the holdout countries. ${ }^{100}$ The Group further suggested that minimum labor standards be defined in an international agreement with reference to ILO conventions in order 'to eliminate international competition based on a country's failure to respect internationally agreed standards, and not to bring about a maximum of uniformity between countries. ${ }^{101}$ No action was taken on this recommendation. ${ }^{102}$

Although the concern about unfairness has been the principal rationale for a labor/trade link, there is a converse tradition of seeking to use trade liberalization as a way to induce countries to raise labor standards. The first champion was James T. Shotwell who, in 1933, proposed to U.S. Secretary of State Cordell Hull that U.S. tariffs be lowered against countries that were taking action to raise wages and standards of living. ${ }^{103}$ Hull rejected the idea. Fifty years later, the idea was revived and made a feature of U.S. trade preference programs. ${ }^{104}$ The European Community also has incorporated a labor provision in its tariff preferences for developing countries. The Community makes available more favorable tariff treatment for countries deemed to be complying with the ILO's core labor standards. ${ }^{105}$

\footnotetext{
${ }^{100}$ Social Aspects of European Economic Co-operation (ILO, 1956), Studies and Reports, New Series, No. 46, paras. 218, 219. The Group of Experts was chaired by the Swedish economist and parliamentary leader Bertil Ohlin. For a tribute to Ohlin, see Jagdish Bhagwati, Protectionism (MIT Press, 1989), xi.

${ }^{101}$ Social Aspects of European Economic Co-operation, supra note 100, para. 220.

${ }^{102}$ Note that the Treaty of Rome of 1957 endorsed the harmonization of national social systems and established a European Social Fund. André Sapir, 'Who's Afraid of Globalization? Domestic Adjustment in Europe and America,' in Roger B. Porter et al., (eds), Efficiency, Equity, and Legitimacy (Brookings, 2001) 179, at 190 (discussing Arts. 117-125 of the Treaty).

${ }^{103}$ James T. Shotwell, The Autobiography of James T. Shotwell (Bobbs-Merrill, 1961), at 308.

${ }^{104}$ Steve Charnovitz, 'Caribbean Basin Initiative: Setting Labor Standards,' 107 Monthly Labor Review, November 1984, 54.

${ }^{105}$ Council Regulation (EC) No 2501/2001 of 10 December 2001 applying a scheme of generalised tariff preferences, OJ 2001 L 346/1.
} 
The labor provisions in contemporary FTAs are derivative of both traditions - the idea of positive incentives and the concern about trade unfairness. Yet the unfairness concerns seem more influential. After all, the cause of action in the U.S.-Chile FTA is lax national enforcement that affects trade between the parties. ${ }^{106}$ Inadequate labor law enforcement that lacks an impact on trade would not be actionable.

Another justification for international labor cooperation emphasizes the role of human resources in economic development. ${ }^{107}$ Recall the attention to 'human capital' at the Pan American Conference of 1933. Promoting fuller employment and better working conditions in each country is in the interest of all because national prosperity has positive spillovers. Once best practices toward human resource development and workplace regulation are determined, then governments will benefit from widespread adoption of such practices. ${ }^{108}$

Note that this rationale may explain why governments cooperate, but does not fully explain why governments would bind themselves in international conventions. One explanation offered by political economists is that a breakdown in the domestic political process may prevent governments from enacting legislation to correct a market failure. ${ }^{109}$ An international requirement to do so is

${ }^{106}$ U.S.-Chile FTA, supra note 56, Art. 18.2(1)(a).

${ }^{107}$ Sarah H. Cleveland, 'Why International Labor Standards?,' in Flanagan and Gould, supra note 53, 129, at 139; Isobel Coleman, 'The Payoff from Women's Rights,' Foreign Affairs, May/June 2004, 80; Ray Marshall, 'The Link Between Labor Standards and Human Capital,' in National Research Council, Human Capital and Investment: Summary of a Workshop (National Academies Press, 2003), 4; Peter Morici, Labor Standards in the Global Trading System (Economic Strategy Institute, 2001), at 43; Sandra Polaski, 'Trade and Labor Standards,' Carnegie Endowment for International Peace, 2003, at 171 .

${ }^{108}$ See Werner Sengenberger, Globalization and Social Progress: The Role and Impact of International Labour Standards (Friedrich Ebert Stiftung, 2002), at 51 (describing international labor standards as international public goods).

${ }^{109}$ Drusilla K. Brown, Alan V. Deardorff, and Robert M. Stern, 'International Labor Standards and Trade: A Theoretical Analysis,' in Bhagwati and Hudec, supra note 95, Vol. 1, 227, at 270-271. 
therefore politically useful for a government to seek and accept. The Japanese term 'gaiatsu' is sometimes employed to describe this strategic use of foreign pressure for domestic reform. The same idea of an external normative push appeared in the 1956 report by the ILO Group of Experts, which explained that 'If international agreement can be reached that the introduction of certain types of social measures is desirable, this will strengthen the hands of those who, in the various countries, are pressing for the introduction of the measures in question., ${ }^{, 10}$

The last rationale to be discussed is not based on a utilitarian purpose, but rather on the deontological ground that workers are to be respected as individuals. ${ }^{111}$ In modern parlance, we capsulize this by saying that labor rights are human rights. ${ }^{12}$ Yet one should also remember that labor rights were conceived as a form of international solidarity well before the modern human rights movement.

International law is premised on the dignity of the worker. As Paul O'Higgins has pointed out, the idea that 'Labour is not a commodity' is a fundamental precept of international labor law originated by the Irish economist, John Kells Ingram, in $1880 .{ }^{113}$ The constitutional act of 1919 creating the ILO declared that '...labour should not be regarded merely as a commodity or article of commerce,' and the ILO Declaration of Philadelphia of 1944 refined this proposition to state: 'labour

\footnotetext{
${ }^{110}$ Social Aspects of European Economic Co-operation, supra note 100, para. 205.

${ }^{111}$ Guy Caire, 'Labour Standards and International Trade,' in Sengenberger and Campbell, supra note 85 , at 297 (discussing the two points of view, namely, the dignity of labor and the economic perspective).

${ }^{112}$ See, e.g., Hans-Michael Wolffgang and Wolfram Feuerhake, 'Core Labour Standards in World Trade Law,' 36 Journal of World Trade 883, at 889 (2002) (discussing 'core labour standards as worker rights equivalent to human rights').

${ }^{113}$ Paul O’Higgins, “' "Labour is not a Commodity”-An Irish Contribution to International Labour Law,' 26 Industrial Law Journal 225, at 233 (1997).
} 
is not a commodity. ${ }^{114}$ Besides the influence of Graham, that idea has a historical basis in religious doctrine, particularly Pope Leo XIII's encyclical of 1891, Rerum Novarum. This encyclical declares that 'It is neither just nor human so to grind men down with excessive labor as to stupefy their minds and wear out their bodies. ${ }^{, 15}$

So far in Part 3, this lecture has sought to explain why governments intervene in the labor market, and why international harmonization is pursued. The next section in Part 3 discusses the choice of law. That is, should labor harmonization be pursued in labor agreements or in trade agreements?

\section{Labor Versus Trade Agreements}

Using a labor treaty to achieve common national objectives on labor would seem to be a more straightforward path than using a trade treaty. Certainly, that was the idea in 1919 when the ILO was created, many decades before a comparable international organization was established to promote common trade objectives. Nevertheless, the assumption underlying the longtime efforts to add a social clauses to trade agreements is that the ILO is inadequate to achieving its purpose. Advocates of using the WTO to reinforce the ILO often contend that '...the ILO does not possess the international legal authority to enforce labour standards against recalcitrant states. ${ }^{\text {'16 }}$

In the Inter-American context, no thought has been given to the idea of adopting regional labor treaties. The global-regional dynamic in labor policy is different than in trade policy, where it is thought that bilateral and regional agreements can play a useful role in supplementing multilateral

\footnotetext{
${ }^{114}$ Compare Treaty of Versailles, supra note 84, Art. 417 and Declaration of the Aims and Purposes of the International Labour Organization (Annex to the current ILO Constitution), sect. I.

${ }^{115}$ Rerum Novarum, 15 May 1891, para. 42, available at http://www.vatican.va/holy_father/leo_xiii/encyclicals.

${ }^{116}$ The quotation comes from Patrick Macklem, 'Labour Law Beyond Borders,' 5 Journal of International Economic Law 605, at 638 (2002).
} 
agreements. Yet no one is arguing that the alleged inadequacies of the ILO should be remedied by a stronger regional labor agreement. ${ }^{117}$

Explaining why is a puzzle. The answer that governments are uninterested in regional labor policy is unsatisfying because, if so, then why would they seek to insert labor provisions in a regional trade agreement? It could be that governments lack frameworks for negotiating labor agreements in the same way that they negotiate trade agreements. ${ }^{118}$ Or it could be that most governments do not want new international labor disciplines, and can only be induced to accept them through linkage to highly-desired trade agreements.

A theory of trade linkage has been developed by David Leebron who distinguishes between two claims - strategic versus substantive linkage. ${ }^{119}$ In strategic linkage, the inclusion of labor in a trade agreement is dictated by political demands from particular countries. In substantive linkage, labor is included in a trade agreement either: (1) because labor and trade norms are related, or (2) because, without a linkage, the trade agreement might undermine labor norms. Leebron calls the first reason 'coherence' and the second 'consequentialist.'

So far, no analyst has taken Leebron's framework and applied it to a trade/labor linkage. All of the international concerns discussed above - a race to the bottom, fairness, and worker dignity would seem to reflect either coherence or consequential aims. Are labor rights consistent with trading rights $?^{120}$ Would a trade agreement be more successful if accompanied by a baseline of core

\footnotetext{
${ }^{117}$ Note that the General Agreement on Trade in Services (GATS) provides some deference to labor market integration agreements. GATS Art. V bis.

${ }^{118}$ This is certainly so in the United States which has a fast track process for approving trade agreements, but does not have one for approving labor agreements.

${ }^{119}$ David W. Leebron, 'Linkages,' 96 AJIL 5, at 11-14 (2002).

${ }^{120}$ See Christopher McCrudden and Anne Davies, 'A Perspective on Trade and Labour Rights,' in Francesco Francioni (ed), Environment, Human Rights and International Trade (Hart, 2001), 179, at 187 (suggesting that labor rights that serve to increase freedom of choice and contract are theoretically consistent with the ideology of free trade and may be required by it).
} 
labor standards? These questions are important and deserve careful answers beyond the scope of these lectures.

However persuasive the rationale for including labor in a trade agreement, governments should also weigh the disadvantages of doing so. ${ }^{121}$ One possible problem is that seeking labor provisions may discombobulate trade negotiations. Another is that the labor disciplines may lead to trade disputes that will undo trade liberalization. To be sure, these objections also apply to other topics of trade linkage, such as intellectual property rights.

Quite apart from any harm of labor linkage to the trade regime is the potential harm to the labor regime. Those who view the ILO and regional labor cooperation as ineffectual would probably not be concerned about such harm. Yet more thoughtful analysts have recognized the substantial benefits of the ILO, including how it helps governments through norm generation and capacity building. ${ }^{122}$ Viewed in this way, the lack of FTA-style enforcement is a virtue of the labor regime rather than a weakness.

Most analysts who advocate the inclusion of labor disciplines in trade agreements prefer either the current United States approach with FTAs, or a more muscular approach that would incorporate ILO standards. In my view, neither path is optimal. In the current FTA approach, governments have crafted a labor discipline that is sufficiently vapid that it won't have any effect on trade flows. Yet if FTAs were to require compliance with core ILO conventions, that would affect

\footnotetext{
${ }^{121}$ See Philip Alston, 'Linking Trade and Human Rights,' 23 German Yearbook of International Law 126, at 157 (1980) (noting that the potential costs of linking trade and human rights may be considerable and calling for a careful weighing process).

${ }^{122}$ Kofi Addo, 'The Correlation Between Labour Standards and International Trade,' 36 Journal of World Trade 285 (2002); Virginia A. Leary, 'Workers' Rights and International Trade: The Social Clause (GATT, ILO, NAFTA, U.S. Laws),' in Bhagwati and Hudec, supra note 95, Vol. 2, 177, at 189; Francis Maupain, 'International Labor Organization Recommendations and Similar Instruments,' in Dinah Shelton (ed.), Commitment and Compliance, The Role of Non-Binding Norms in the International Legal System (Oxford, 2003), 372, at 392 (positing that bindingness is not the essence of international law); Salazar-Xirinachs and Martínez-Piva, supra note 49, at 332-334.
} 
trade flows, and potentially make it harder for developing countries to expand their exports. ${ }^{123}$

Furthermore, both paths are inadequate because they miss opportunities to zero in on a few important trade and labor connections. Part 4 will present my own recommendations for how to incorporate a labor dimension into the FTAA.

\section{Recommendations for the FTAA}

A quarter century ago, the ILO annual conference passed a resolution requesting governments

to:

see that the trade agreements concluded within the framework of appropriate institutions promote both the expansion of world trade and the local utilisation of the labour force available in various countries and make it possible to achieve a real improvement of the standard of living of the populations in accordance with the objectives of international labour standards in so far as they have been ratified. ${ }^{124}$

The resolution is noteworthy because it is a rare instance of an ILO pronouncement on trade agreements. The ILO's advice was well-crafted. The expansion of world trade can be good for workers, ${ }^{125}$ but the actual outcome depends on the design of the trade agreement. Various features in a trade agreement can affect the amount of job creation, workplace conditions, and prospects for a rising standard of living.

If the FTAA is to have a labor dimension, its member governments should be bolder and more innovative than in existing Inter-American free trade agreements. Provisions are needed to do the following: (A) Enhance the consumer role in the labor market, (B) Promote worker adjustment, (C)

\footnotetext{
${ }^{123}$ This is so whether compliance is induced through trade sanctions or monetary penalties. An FTAA labor provision enforced with monetary penalties is recommended by Bobbi-Lee Meloro, 'Balancing the Goals of Free Trade with Workers' Rights in a Hemispheric Economy,' 30 University of Miami Inter-American Law Review 433, at 458 (1998).

${ }^{124}$ International Labour Conference, $65^{\text {th }}$ Session, 1979, Record of Proceedings, Resolution Concerning the Follow-up to the World Employment Conference, lxxxiv, at $x c$.

${ }^{125}$ Recall the 1939 resolution of the American States which are Members of the ILO, see text accompanying supra note 35 .
} 
Disallow prohibitions of unions in export processing zones, and (D) Expand protection for migrant workers. Part 4 presents these recommendations and then concludes the lecture.

\section{A. Enhance the Consumer Role}

Although government regulation and subsidies can play an important part in correcting labor market failures, they are not the only tools available. Governments can also facilitate efforts by consumers to seek more socially responsive practices by businesses. The consumer is empowered when he has reliable information about the employment conditions of the workers who produce the products that he buys. Such information can be facilitated by social labels, industry partnerships, and voluntary codes of conduct that are carefully monitored. ${ }^{126}$ The worker is helped when her employer follows best practices in labor relations and seeks to invest in its employees.

How should a trade agreement catalyze such changes? Not through heavy-handed rules, but rather by improving regulatory transparency, encouraging national stakeholder dialogues, and using consultative mechanisms at the international level. As noted in Table 1, the Association Agreement between the EC and Chile provides one example in its provisions on social dialogue. ${ }^{127}$ The FTAA

\footnotetext{
${ }^{126}$ Ian Graham and Andrew Bibby, 'Global Labour Agreements: A Framework for Rights,' World of Work, December 2002, 4; Janet Hilowitz, 'Social Labelling to Combat Child Labour: Some Considerations,' 136 International Labour Review 215 (1997); Vitit Muntarbhorn, 'International Commerce and the Rights of the Child,' in Jean-François Flauss et al. (eds), World Trade and the Protection of Human Rights (Bruylant, 2001), 151, at 167-174 (discussing catalytic role of stakeholders); Nick Robins and Liz Humphrey, Sustaining the Rag Trade (IIED, 2000); Christoph Scherrer and Thomas Greven, Global Rules for Trade: Codes of Conduct, Social Labeling, Workers' Rights Clauses (Westfälisches Dampfboot, 2001); Gijsbert van Liemt, 'Codes of Conduct and International Subcontracting: A "Private" Road Towards Ensuring Minimum Labour Standards in Export Industries,' in Blanpain, supra note 56, at 167; Philip von Schôppenthau, 'Trade and Labour Standards: Harnessing Globalisation?,' in Klaus Günter Deutsch and Bernhard Speyer (eds), The World Trade Organization Millennium Round (Routledge, 2001), 224, at 232-234 (discussing codes of conduct); Robert Wai, 'Countering, Branding, Dealing: Using Economic and Social Rights in and around the International Trade Regime,' 14 EJIL 35, at 73 (2003) (discussing branding).

${ }^{127}$ Recently, Robert Pastor proposed a North American interparliamentary group. Robert A. Pastor, 'North America's Second Decade,' Foreign Affairs, January/February 2004, 124.
} 
could adopt that approach, and could also establish a network of the ongoing labor promotional activities in the NAALC, Mercosur, and other agreements of regional integration.

\section{B. Promote Worker Adjustment}

International trade will make a country better off as a whole, and yet some individuals may be left worse off. Therefore, governments should seek to broaden the distribution of the benefits from trade and deliver adjustment assistance to workers who suffer extended dislocations. That government role is sometimes called a 'safety net, ${ }^{128}$ but that term seems too reactive. The aim of an adjustment program should not only be to protect workers from catastrophic impacts, but also to proactively help them find decent work in a changing economy. The instruments available include retraining, relocation allowances, and other employability assistance.

As noted in Part 1, the need for governmental efforts to accord 'economic security' in the Americas was perceived over 50 years ago, and the ILO regional conference of 1946 called for 'training and retraining of adult workers.' Yet despite these resolutions, very little has been done on a regional basis to promote worker adjustment. In 2002, the 7th FTAA Ministerial conference of 2002 (Quito Declaration) suggested the idea of a Hemispheric Cooperation Program that would, among other tasks, strengthen the capacity of countries in 'adjusting to integration.' ${ }^{129}$ But to my knowledge, nothing concrete has been done to implement such a program or to improve the delivery of worker adjustment assistance.

Given that the benefits of a good national worker adjustment program would accrue primarily to that nation's own economy, governments should not need any fillip to carry out such programs.

\footnotetext{
${ }^{128}$ Raymond Torres, Towards A Socially Sustainable World Economy (ILO, 2001), at 56 (discussing social safety nets).

${ }^{129}$ Ministerial Declaration, 1 November 2002, available at http://www.ftaaalca.org/Ministerials/Quito, Annex III.
} 
Sadly, though, many governments tend to be lackadaisical about responding to economic dislocations. ${ }^{130}$ Even the U.S. government, the biggest spender in the Americas, underinvests in such programs.

One idea for increasing governmental attention to worker adjustment would be to internationalize the issue. As Philip Alston has noted, ILO Director-General C. Wilfred Jenks gave an address to the UN Economic and Social Council in 1971 in which he posited an ILO role in the '... adoption of effective manpower adjustment measures calculated to facilitate trade liberalization measures by eliminating or reducing some of the grounds for opposition to them. ${ }^{131}$ Jenks was right to perceive labor adjustment as an international challenge, and to see the connection to gaining public support for trade. In 1976, the ILO World Employment Conference advocated 'active manpower policies and adjustment assistance' and stated that 'Adjustment assistance is considered preferable to import restrictions. ${ }^{, 132}$

Other stakeholders who recognized worker adjustment as an international problem suggested that it be taken up by the trading system. For example, in the early 1970s, the International Metalworkers' Federation proposed adding a 'social clause' to the General Agreement on Tariffs and Trade that would combine developing country job creation through new exports with industrial

\footnotetext{
${ }^{130}$ See C. Fred Bergsten, 'Foreign Economic Policy for the Next President,' Foreign Affairs, March/April 2004, 88, at 96-97; Mack McLarty, 'Trade Paves Path to U.S. Prosperity,' Los Angeles Times, 1 February 2004, 2; Jaime Saavedra, 'Labor Markets During the 1990s,' in Pedro-Pablo Kuczynski and John Williamson (eds), After the Washington Consensus. Restarting Growth in Latin America (Institute for International Economics, 2003), Chap. 9; Bruce Stokes, 'Rural Poor Need Trade and Aid,' National Journal, 31 May 2003, 1710.

${ }^{131}$ Philip Alston, 'International Trade as an Instrument of Positive Human Rights Policy,' 4 Human Rights Quarterly 155, at 176 (1982).

${ }^{132}$ ILO, Declaration of Principles and Programme of Action Adopted by the 1976 World Employment Conference, paras. 63, 69, reprinted in Employment, Growth and Basic Needs: A One-World Problem (Praeger, 1977), 189, at 202-203.
} 
country efforts to give affected workers employment and income guarantees. ${ }^{133}$ To my knowledge, the first proposal to include adjustment in a free trade agreement came in 1993, when Robert Howse suggested providing a 'right' to worker adjustment in the NAFTA. ${ }^{134}$ Howse's proposal did not specify a package of benefits, but rather sought a commitment of the trading partners to deliver adjustment and to coordinate their efforts. His proposal was not adopted either in the NAFTA or in the labor side agreement.

Howse's idea continues to have merit, however, and governments should include a basic commitment to worker adjustment within the FTAA. The richer governments in the region should provide financial assistance to adjustment programs in other countries, and all the governments should cooperate to develop quality standards for training programs. By making a commitment to worker adjustment, each country could, over time, lessen public opposition to trade agreements, and reduce the social and economic losses stemming from prolonged unemployment.

In 2003, the WTO Secretariat issued a study on 'Adjusting to Trade Liberalization' that devotes a chapter to how 'Governments can facilitate the adjustment process.' This chapter discusses social safety nets, labor markets, education and training, and other issues. ${ }^{135}$ Although this WTO effort to delve into labor issues is commendable, the study was a disappointment because it ignored the opportunity for international cooperation. Indeed, the attention given to the international level is

\footnotetext{
${ }^{133}$ Report of the ILO Director-General, 1976, reprinted in Employment, Growth and Basic Needs: A One-World Problem, supra note 132, 1, at 122.

${ }^{134}$ Robert Howse, 'The Case for Linking a Right to Adjustment with the NAFTA,' in Jonathan Lemco and William B.P. Robson (eds), Ties Beyond Trade (Canadian-American Committee, 1993), 79.

${ }^{135}$ WTO Secretariat, Adjusting to Trade Liberalization, Special Study 7, April 2003, Chap. V, available on WTO website.
} 
perverse, with the Secretariat instructing governments on how to delay trade liberalization by using lengthy transition periods and imposing temporary import protection. ${ }^{136}$

\section{Disallow Bans on Unions in Export Zones}

No one can seriously deny that the issue of worker rights in export processing zones (EPZs) is related to trade, and can be properly addressed within a trade agreement. Nevertheless, no FTA contains standards for how workers are treated in such zones. Yet EPZs in many countries engage in severe abuses of fundamental worker rights. ${ }^{137}$

Crafting an FTAA rule for EPZs would be a challenge. The ILO lacks any conventions or recommendations on this topic. Surely it is too simplistic to say that EPZs should follow the same labor law that otherwise exists in a country, as that law could be too low to guarantee internationallyrecognized labor rights. On the other hand, prevailing law could be so restrictive that it inhibits investment. For a long time, many countries in Latin America suffered an enervating combination of excessive import protection combined with excessive de jure labor protection, with a consequent loss of investment and employment opportunities. ${ }^{138}$

My recommendation is that FTAA governments start with one basic rule - that EPZs must not forbid trade unions - and incorporate that into the FTAA. That rule would require some elaboration, of course, but governments should not try to import everything from the authoritative ILO conventions on freedom of association and collective bargaining. Any complaint raised would need to be premised on the FTAA rule, even against governments that are party to core ILO conventions.

\footnotetext{
${ }^{136}$ Id., Chap. VI.

${ }^{137}$ International Confederation of Free Trade Unions, 'Export Processing Zones - Symbols of Exploitation and a Development Dead End,' September 2003. See also Lori Wallach and Patrick Woodall, Whose Trade Organization? (The New Press, $2^{\text {nd }}$ ed. 2004), at 224 (discussing export promotion zones).

${ }^{138}$ See Roger Plant, Labour Standards and Structural Adjustment (ILO, 1994), at 85-90 (discussing the Latin American experience with inflexible labor markets).
} 
The complaint procedure I envision is victim-to-state, not state-to-state. The rationale for a victim-to-state mechanism is that it depoliticizes the dispute system so that no government is saddled with having to espouse the claims of its citizens. Perhaps one reason why no NAFTA labor case was ever filed is that the target government might consider that an unfriendly act.

The complaint process would be similar to the investor-state arbitration in NAFTA except that an individual would also be able to lodge a complaint about the actions of its own government, rather than only a foreign government. Criteria would be needed to establish eligibility to lodge a complaint, and I favor a flexible procedure that permits complaints from individual victims, unions, and public interest groups. A valid complaint about an EPZ would lead to the appointment of an independent panel similar to the panels available for FTA commercial disputes. The worker would not have a right of action against the employer. Cases of that sort would need to remain in national tribunals. Even so, a screening mechanism should be set up to protect a company's reputation from being injured by frivolous complaints.

If the panel rules against the defendant government, the government would be given time to correct the violation, but if no correction ensues, the scofflaw government should be required to pay a fine until the matter is corrected. The fine would be paid to the independent FTAA commission, which could use the money for its regular programs.

Because the EPZ mechanism suggested here differs so much from the labor mechanism provided for in the CAFTA, it may be useful to summarize those differences. My proposal is based on an international rule (to be formulated in the FTAA), while CAFTA is based on each country's own domestic law. ${ }^{139}$ My proposal provides for a private right of action, while CAFTA is state-tostate. $^{140}$ My proposal allows an individual to secure an independent panel, while in CAFTA, an

\footnotetext{
${ }^{139}$ See CAFTA, supra note 57, Art. 16.2(1)(a).
}

${ }^{140}$ See id., Art. 20.6. 
individual submits a communication to an office in its country. ${ }^{141}$ My proposal provides for a financial sanction in the event of non-compliance, while in CAFTA, the scofflaw government pays a monetary assessment to the CAFTA commission, with that money being used for labor initiatives in the defendant country. ${ }^{142}$ My proposal is probably too bold to get enacted, but it would be an interesting experiment that could fructify a right to form and join a free trade union in EPZs.

\section{Expand Protection for Migrant Workers}

Although FTAs seek to liberalize the movement of goods, services, and capital, they have tended to given little attention to the movement of people. Yet worker mobility is logically a part of economic integration, and, like importing and exporting, can benefit both the sending and receiving countries. ${ }^{143}$ This principle is recognized with regard to temporary entry for business executives and professionals, and the same need also exists for less-skilled workers.

The issue of labor mobility has been addressed in some Inter-American trade agreements. Most notably, the Caribbean Community provides for the free movement of university graduates and those in listed occupations. ${ }^{144}$ The NAFTA contains a chapter on Temporary Entry for Business Persons, as do the U.S. and Canada FTAs with Chile. ${ }^{145}$ But the CAFTA does not because, in 2003, the U.S. government got queasy from making immigration commitments in trade agreements. ${ }^{146}$ For

${ }^{141}$ See id., Art. 16.4 The government is obliged only to review the communication and to make it public, as appropriate.

${ }^{142}$ See id., Art. 20.17(4).

${ }^{143}$ 'Trade Goes Global, Labour Remains Local,' Economiquity, No. 26, 2003, at 1; Demetrios G. Papademetriou, 'The Shifting Expectations of Free Trade and Migration,' in NAFTA's Promise and Reality (Carnegie Endowment, 2004), 39.

${ }^{144}$ See 'Free Movement of Skills,' available on http://www.caricom.org.

${ }^{145}$ North American Free Trade Agreement, 17 December 1992, Chap. 16; U.S.-Chile FTA, supra note 56, Chap. 14; Free Trade Agreement between the Government of Canada and the Government of the Republic of Chile, 5 December 1996, Chap. K. 
the United States, it seems that very little has changed since 1928 when it told the Pan American conference that the control of immigration 'is a matter of purely domestic concern.... ${ }^{147}$ The ongoing FTAA talks have neglected even to set up a negotiating group for temporary entry.

If freer immigration cannot be achieved within the FTAA, then governments might instead try to negotiate provisions for greater protection of migrant workers. Relevant international norms already exist, ${ }^{148}$ and key guarantees could be incorporated into the FTAA in the same manner that guarantees from intellectual property treaties will probably be incorporated. Establishing rules for the benefit of migrant workers in the FTAA would help individuals who are commonly exploited. Such rules would have synergies with ongoing regional cooperation on migration policy. ${ }^{149}$

\section{E. Summary and Overall Conclusion}

The ideas in Part 4 seek to stimulate practical, concerted action to address labor and employment problems of regional economic integration. My recommendations for the FTAA do not include an obligation to adhere to core ILO conventions. However one weighs the advantages and disadvantages of that course, such fusion is unlikely to be accepted by FTAA governments. As for the reciprocal obligation to enforce national law, it should be omitted unless governments are willing to replace the current window dressing with a private right of action.

\footnotetext{
${ }^{146}$ See Christopher S. Rugaber, 'Senate Judiciary Committee Members Criticize USTR on Temporary Entry Provision,' BNA International Trade Reporter, 17 July 2003, 1216.

${ }^{147}$ See text accompanying supra note 15 .

${ }^{148}$ See T. Alexander Aleinikoff and Vincent Chetail (eds), Migration and International Legal Norms (Asser Press, 2003). Some of the key norms are protection against discrimination, access to health care, and a right to depart and reenter.

${ }^{149}$ International Organization for Migration, 'Illustration of Multilateral, Regional and Bilateral Cooperative Arrangements in the Management of Migration,' in Aleinikoff and Chetail, supra note 148,305 , at 310-315, 331-333.
} 
Contemporary FTAs seem designed to assist global corporations and devote little attention to those without power or wealth. If governments were to get serious about helping vulnerable workers, then such action could help to humanize trade agreements and lead to more widely shared prosperity. 